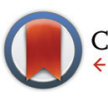

CrossMark $\leftarrow$ click for updates

Cite this: Dalton Trans., 2015, 44 7411

Received 29th January 2015 Accepted 12th March 2015

DOI: $10.1039 / c 5 d t 00418 \mathrm{~g}$

www.rsc.org/dalton

\title{
Preparation of pyranylidene complexes of ruthenium $\uparrow$
}

\author{
Gabriele Albertin, ${ }^{\star a}$ Stefano Antoniutti, ${ }^{a}$ Marco Bortoluzzi, ${ }^{a}$ Alessandra Botter ${ }^{\mathrm{a}}$ and \\ Jesús Castro ${ }^{b}$
}

\begin{abstract}
The reaction of the chloro-complex $\mathrm{RuCl}\left(\eta^{5}-\mathrm{C}_{5} \mathrm{H}_{5}\right)\left(\mathrm{PPh}_{3}\right)\left[\mathrm{P}(\mathrm{OMe})_{3}\right]$ with alkylpropiolates $\mathrm{HC} \equiv \mathrm{CCOOR} 1$ in alcohol R2OH affords pyranylidene derivatives $\left[\mathrm{Ru}\left(\eta^{5}-\mathrm{C}_{5} \mathrm{H}_{5}\right)\{=\overline{\mathrm{C}(\mathrm{COOR} 1) \mathrm{C}(\mathrm{H}) \mathrm{C}(\mathrm{H}) \mathrm{C}(\mathrm{OR} 1) \mathrm{O}}\}\left(\mathrm{PPh}_{3}\right)-\right.$ $\left.\left\{\mathrm{P}(\mathrm{OMe})_{3}\right\}\right] \mathrm{BPh}_{4}(\mathbf{1}, \mathbf{3})$ and alkoxycarbene complexes $\left[\mathrm{Ru}\left(\eta^{5}-\mathrm{C}_{5} \mathrm{H}_{5}\right)\left\{=\mathrm{C}(\mathrm{OR} 2)\left(\mathrm{CH}_{2} \mathrm{COOR} 1\right)\right\}\left(\mathrm{PPh}_{3}\right)\left\{\mathrm{P}(\mathrm{OMe})_{3}\right\}\right]-$ $\mathrm{BPh}_{4}(\mathbf{2}, \mathbf{4})$. A reaction path for the formation of compounds 1-4, involving reactions on a vinylidene intermediate complex, is also discussed. The complexes were characterized spectroscopically (IR and $\left.{ }^{1} \mathrm{H},{ }^{13} \mathrm{C},{ }^{31} \mathrm{P} N M R\right)$ and by $\mathrm{X}$-ray crystal structure determination of $\left[\mathrm{Ru}\left(\eta^{5}-\mathrm{C}_{5} \mathrm{H}_{5}\right)\right.$ $\left.\{=C(\mathrm{COOMe}) \mathrm{C}(\mathrm{H}) \mathrm{C}(\mathrm{H}) \mathrm{C}(\mathrm{OMe}) \mathrm{O}\}\left(\mathrm{PPh}_{3}\right)\left\{\mathrm{P}(\mathrm{OMe})_{3}\right\}\right] \mathrm{BPh}_{4}(\mathbf{1})$.
\end{abstract}

\section{Introduction}

Despite the large number of Fischer-type transition metal carbene complexes reported so far, ${ }^{1}$ six-membered pyranylidene carbene derivatives (Chart 1) are relatively few and involve mainly $\mathrm{Cr}$, Mo and $\mathrm{W}$ central metals. ${ }^{2-5}$ This fact is somewhat surprising, given the increasing interest in their use in ring-opening reactions, ${ }^{6}$ Diels-Alder reactions ${ }^{4 b, 7}$ and 1,6 addition. ${ }^{4 a}$ Several methods for the synthesis of pyranylidene have been developed, mainly including the reaction of preformed carbene complexes with pyridinium ylides, ${ }^{2 b, c}$ enol ethers $^{8}$ and 1,3-diketones, ${ }^{3}$ or multicomponent species ${ }^{9}$ such as alkynyl esters and $\mathrm{N}$-methylmorpholine- $\mathrm{N}$-oxide. Alternatively, pyranylidene complexes can be prepared from the reaction of $\mathrm{M}(\mathrm{CO})_{5} \mathrm{~L}\left(\mathrm{M}=\mathrm{Cr}, \mathrm{Mo}, \mathrm{W} ; \mathrm{L}=\mathrm{THF}, \mathrm{NEt}_{3}\right)$ with $\beta$-alkynyl $\alpha, \beta$-unsaturated carbonyl compounds ${ }^{4}$ and from the reaction of $\mathrm{M}(\mathrm{CO})_{6}$ with 1-lithio-1,3-dienes. ${ }^{5}$ However, in only one case the simplest method for preparing a pyranylidene complex, involving dimerization of alkylpropiolate $\mathrm{HC} \equiv \mathrm{CCOOR}$ on a metal fragment, has been reported. ${ }^{9}$

We were interested in the reactivity of half-sandwich complexes containing phosphite ligands ${ }^{10}$ and, in the course of our studies, found that the reaction of the complex $\operatorname{RuCl}\left(\eta^{5}\right.$ $\left.\mathrm{C}_{5} \mathrm{H}_{5}\right)\left(\mathrm{PPh}_{3}\right)\left[\mathrm{P}(\mathrm{OMe})_{3}\right]$ with alkylpropiolate leads to the first pyranylidene complexes of ruthenium. Our results, including

\footnotetext{
${ }^{a}$ Dipartimento di Scienze Molecolari e Nanosistemi, Università Ca' Foscari Venezia, Dorsoduro 2137, 30123 Venezia, Italy. E-mail: albertin@unive.it

${ }^{b}$ Departamento de Quimica Inorgánica, Universidade de Vigo, Facultade de Quimica, Edificio de Ciencias Experimentais, 36310 Vigo, Galicia, Spain

$\dagger$ Electronic supplementary information (ESI) available: $x y z$ file for DFT-optimized structures; NMR spectra (pdf). CCDC 1046060. For ESI and crystallographic data in CIF or other electronic format see DOI: 10.1039/c5dt00418g
}

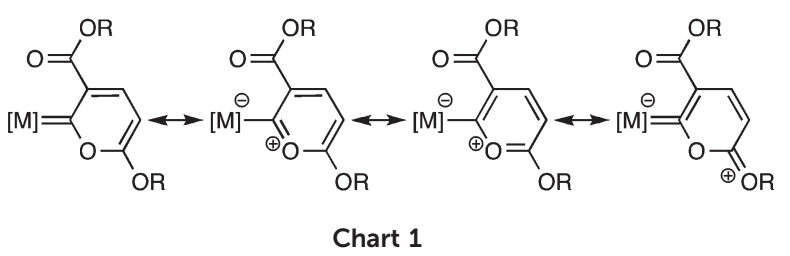

the synthesis and characterization of pyranylidene and alkoxycarbene complexes of $\mathrm{Ru}(\mathrm{II})$, are reported here.

\section{Results and discussion}

The half-sandwich chloro-complex $\operatorname{RuCl}\left(\eta^{5}-\mathrm{C}_{5} \mathrm{H}_{5}\right)\left(\mathrm{PPh}_{3}\right)$ $\left[\mathrm{P}(\mathrm{OMe})_{3}\right]$ reacts with an excess of alkylpropiolate $\mathrm{HC} \equiv \mathrm{CCOOR} 1$ in alcohol $\mathrm{R} 2 \mathrm{OH}$ to give a mixture of pyranylidene $\quad\left[\mathrm{Ru}\left(\eta^{5}-\mathrm{C}_{5} \mathrm{H}_{5}\right)\{=\overline{\mathrm{C}(\mathrm{COOR} 1) \mathrm{C}(\mathrm{H}) \mathrm{C}(\mathrm{H}) \mathrm{C}(\mathrm{OR} 1) \mathrm{O}}\}\left(\mathrm{PPh}_{3}\right)^{-}\right.$ $\left.\left\{\mathrm{P}(\mathrm{OMe})_{3}\right\}\right] \mathrm{BPh}_{4} \quad(\mathbf{1}, \quad 3)$ and alkoxycarbene $\left[\mathrm{Ru}\left(\eta^{5}-\mathrm{C}_{5} \mathrm{H}_{5}\right)-\right.$ $\left.\left\{=\mathrm{C}(\mathrm{OR} 2)\left(\mathrm{CH}_{2} \mathrm{COOR} 1\right)\right\}\left(\mathrm{PPh}_{3}\right)\left\{\mathrm{P}(\mathrm{OMe})_{3}\right\}\right] \mathrm{BPh}_{4}(2,4)$ in about $1: 4$ ratio, which were separated by fractional crystallization and characterized (Scheme 1).

Crucial for successful syntheses was the use of alcohol containing the salt $\mathrm{NaBPh}_{4}$ as a solvent, which probably favors substitution of the chloride ligand in the starting complex, yielding the two types of complexes 1, 3 and $2, \mathbf{4}$.

The formation of both pyranylidene and alkoxycarbene derivatives in the reaction of $\operatorname{RuCl}\left(\eta^{5}-\mathrm{C}_{5} \mathrm{H}_{5}\right)\left(\mathrm{PPh}_{3}\right)\left[\mathrm{P}(\mathrm{OMe})_{3}\right]$ with alkylpropiolate is somewhat surprising, but may be explained according to the reaction path shown in Scheme 2, which involves the initial formation of a vinylidene intermediate $[\mathbf{A}]$. Reaction of this intermediate with alkylpropiolate gives 


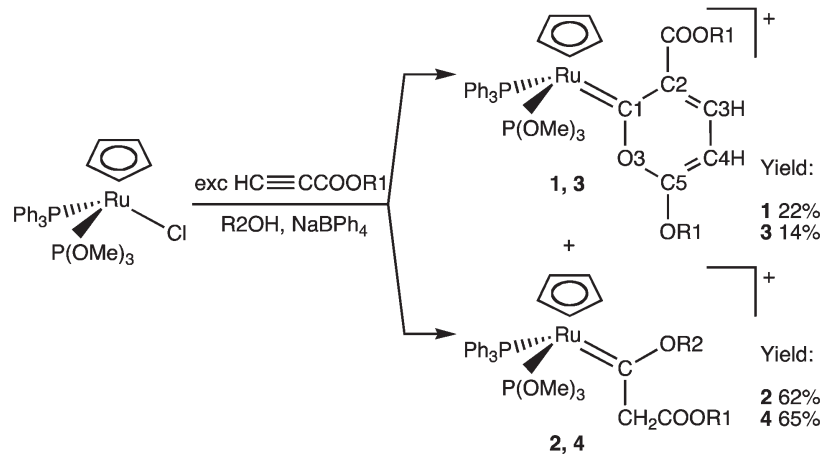

Scheme 1 R1 = Me (1, 2), Et $(3,4) ; R 2=M e(a)$, Et $(b)$.
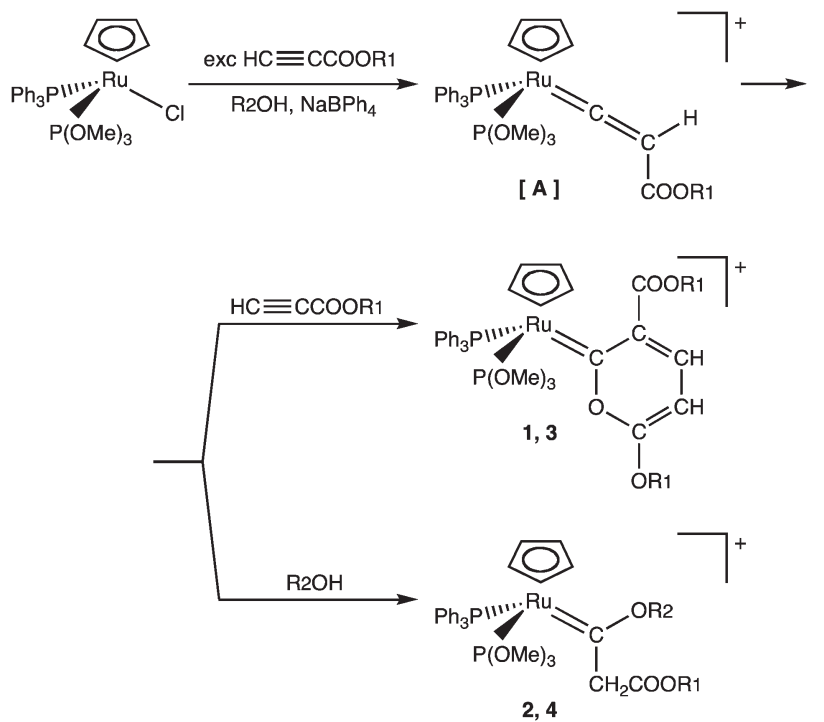

Scheme 2 R1 = Me, Et; R2 = Et.

rise to the dimerization of $\mathrm{HC} \equiv \mathrm{CCOOR} 1$, affording pyranylidene derivatives 1, 3. Parallel nucleophilic attack by the oxygen atom of $\mathrm{R} 2 \mathrm{OH}$ on the $\mathrm{C} \alpha$ of the vinylidene, followed by proton-transfer, yields the final alkoxycarbene derivatives $\mathbf{2 ,} 4$.

In order to verify this reaction path, we attempted to isolate the vinylidene intermediate $[\mathbf{A}]$ or, at least, to identify it in the reaction mixture. At first, we treated the compound $\operatorname{RuCl}\left(\eta^{5}-\right.$ $\left.\mathrm{C}_{5} \mathrm{H}_{5}\right)\left(\mathrm{PPh}_{3}\right)\left[\mathrm{P}(\mathrm{OMe})_{3}\right]$ with $\mathrm{HC} \equiv \mathrm{CCOOR} 1$, in the presence of $\mathrm{NaBPh}_{4}$, in a solvent other than alcohol such as dichloromethane, but no reaction was observed, probably owing to the insolubility of $\mathrm{NaBPh}_{4}$ in this solvent. We therefore used a different strategy, involving a reaction of the starting chlorocomplex first with silver triflate, to form the triflate intermediate $\mathrm{Ru}\left(\kappa^{1}-\mathrm{OTf}\right)\left(\eta^{5}-\mathrm{C}_{5} \mathrm{H}_{5}\right)\left(\mathrm{PPh}_{3}\right)\left[\mathrm{P}(\mathrm{OMe})_{3}\right]$, and then with an excess of methylpropiolate in dichloromethane as a solvent (Scheme 3).

The triflate complex quickly reacted with methylpropiolate by changing color in the solution, from which we were not able to isolate a solid, but only an oily product. Its ${ }^{13} \mathrm{C}$ NMR spectrum showed a doublet of doublets at $199.71 \mathrm{ppm}\left(J_{\mathrm{CP}}=\right.$

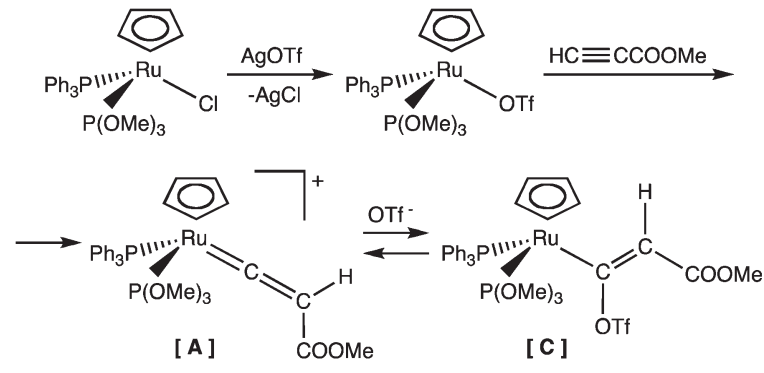

Scheme 3

$15.9, J_{\mathrm{CP}}=11.6 \mathrm{~Hz}$ ), which might be attributed to the $\mathrm{C} \alpha$ carbon atom of a vinylidene species $[\mathbf{A}]$. However, this value is at lower frequency than those observed for the $\mathrm{C} \alpha$ of several known vinylidene derivatives. ${ }^{11}$ As suggested by a reviewer, this resonance may be attributed to the $\mathrm{C} \alpha$ of the vinyl species $\quad\left[\mathrm{Ru}\left(\eta^{5}-\mathrm{C}_{5} \mathrm{H}_{5}\right)\{\mathrm{C}(\mathrm{OTf})=\mathrm{C}(\mathrm{H}) \mathrm{COOMe}\}\left(\mathrm{PPh}_{3}\right)\left[\mathrm{P}(\mathrm{OMe})_{3}\right]\right.$ $[\mathrm{C}]$, formed by nucleophilic attack of the triflate ion on the carbene carbon atom of the $=\mathrm{C}=\mathrm{C}(\mathrm{H}) \mathrm{COOMe}$ ligand. In an HMBC experiment, the ${ }^{13} \mathrm{C}$ signal at $199.7 \mathrm{ppm}$ is correlated with the multiplet at $5.47 \mathrm{ppm}$ of the ${ }^{1} \mathrm{H}$ spectrum, attributable to the $=\mathrm{C}(\mathrm{H}) \mathrm{COOMe}$ of the vinyl ligand, fitting the proposed formulation for $[\mathbf{C}]$. The triflate ligand is labile in the complex $\mathrm{Ru}\left(\kappa^{1}-\mathrm{OTf}\right)\left(\eta^{5}-\mathrm{C}_{5} \mathrm{H}_{5}\right)\left(\mathrm{PPh}_{3}\right)\left[\mathrm{P}(\mathrm{OMe})_{3}\right]$ and can be substituted by alkyne, which then tautomerizes ${ }^{11}$ on the metal center to give vinylidene intermediate $[\mathbf{A}]$. Reaction with the triflate ion $\mathrm{OTf}^{-}$can give the vinyl intermediate $[\mathrm{C}]$, which may be in equilibrium with $[\mathbf{A}]$ (Scheme 3). DFT calculations on model systems, where P-donor ligands are replaced by $\mathrm{PH}_{3}$ and $\mathrm{PF}_{3}$, support this hypothesis, the $\Delta H$ difference between $\left[\mathrm{Ru}\left(\eta^{5}-\mathrm{C}_{5} \mathrm{H}_{5}\right)\{\mathrm{C}(\mathrm{OTf})=\mathrm{C}(\mathrm{H}) \mathrm{COOMe}\}\left(\mathrm{PH}_{3}\right)\left(\mathrm{PF}_{3}\right)\right]$ and $\left[\mathrm{Ru}\left(\eta^{5}-\right.\right.$ $\left.\left.\mathrm{C}_{5} \mathrm{H}_{5}\right)\{=\mathrm{C}=\mathrm{C}(\mathrm{H}) \mathrm{COOMe}\}\left(\mathrm{PH}_{3}\right)\left(\mathrm{PF}_{3}\right)\right]$ OTf being only about $1.2 \mathrm{kcal} \mathrm{mol}^{-1}$ in favor of the latter. The fact that vinylidene $[\mathbf{A}]$ and/or vinyl $[\mathbf{C}]$ complexes are really intermediates of the reaction path proposed in Scheme 2 was confirmed by treatment with ethanol, which gave ethoxycarbene $\mathbf{2 b}$ as the final product, the addition of methanol affording methoxycarbene 2a. Instead, addition of alkylpropiolate to vinylidene intermediate $[\mathbf{A}]$ only yielded traces of the pyranylidene complex, and it was only with the addition of alcohol to the solution of $[\mathbf{A}]$ that the reaction started, affording a mixture of pyranylidene 1 and alkoxycarbene 2 complexes. However, the greater amount of carbene 2 with respect to pyranylidene ( $4: 1$ ratio) suggests a faster reaction of vinylidene $[\mathbf{A}]$ with alcohol than that with propiolate.

The need for alcohol as a solvent is explained by the fact that the formation of pyranylidene from the reaction of vinylidene $[\mathbf{A}]$ with alkylpropiolate must involve a hydrogen shift, which may be a proton transfer strongly favored by protic solvents such as alcohols (Scheme 4).

In fact, plausible mechanisms for the formation of the pyranylidene probably involve cyclization reactions between an alkylpropiolate molecule and coordinated vinylidene or $\eta^{2}$ alkyne, affording intermediates [B1] (path 1) or [B2] (path 2), 


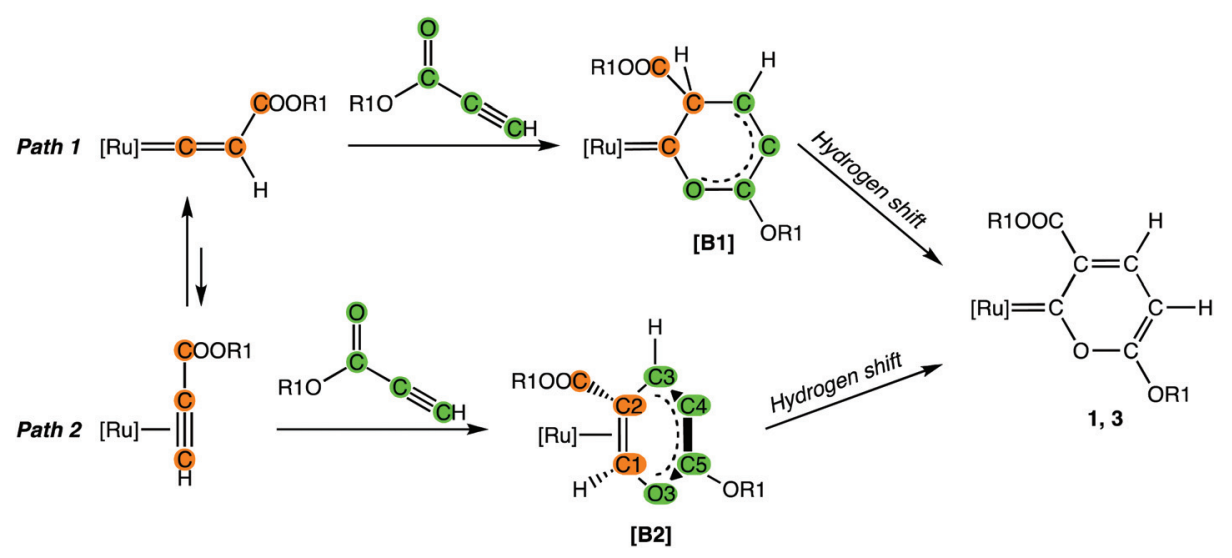

Scheme $4 \quad[\mathrm{Ru}]=\left[\mathrm{Ru}\left(\eta^{5}-\mathrm{C}_{5} \mathrm{H}_{5}\right)\left(\mathrm{PPh}_{3}\right)\left\{\mathrm{P}(\mathrm{OMe})_{3}\right\}\right]^{+} ; \mathrm{R} 1=\mathrm{Me}, \mathrm{Et}$.

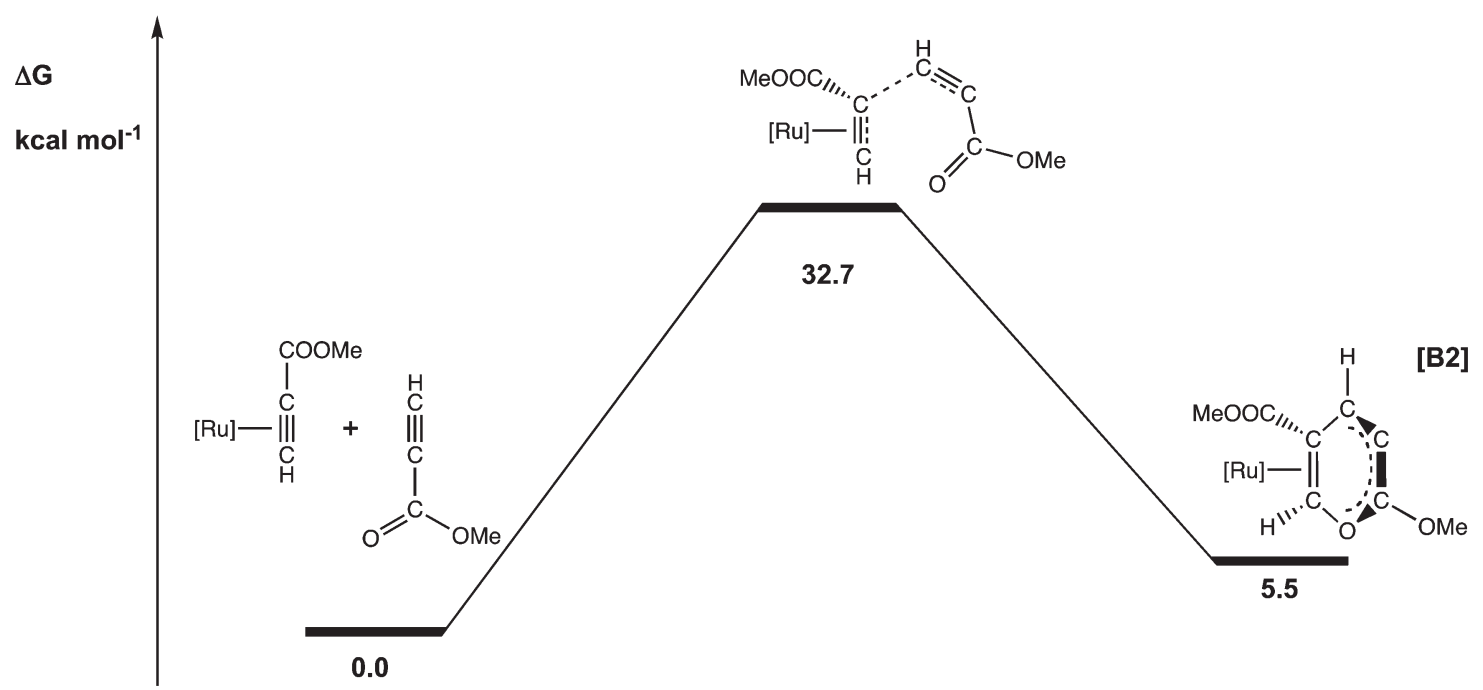

Scheme 5 Computed reaction pathway for the formation of [B2] from $\left\{[R u]-\eta^{2}-H C \equiv C H+\right.$ methylpropiolate $\} .[R u]=\left[R u\left(\eta^{5}-C_{5} H_{5}\right)\left(P H_{3}\right)\left(P F_{3}\right)\right]^{+}$.

respectively. Subsequent hydrogen transfers in these intermediates gave the final pyranylidene complexes 1,3 . DFT calculations on a simplified system, in which $[\mathrm{Ru}]=\left[\mathrm{Ru}\left(\eta^{5}-\mathrm{C}_{5} \mathrm{H}_{5}\right)\right.$ $\left.\left(\mathrm{PH}_{3}\right)\left(\mathrm{PF}_{3}\right)\right]^{+}$and $\mathrm{R} 1=\mathrm{Me}$ (see ESI $\dagger$ ), indicated the formation of intermediate [B2], which is about $20.7 \mathrm{kcal} \mathrm{mol}^{-1}$ more stable than [B1]. The final formation of the pyranylidene derivative is strongly favored, as its Gibbs energy is lower than that of [B2] by about $53.8 \mathrm{kcal} \mathrm{mol}^{-1}$. DFT calculations ruled out intramolecular pathways for the hydrogen shift from [B2] to the final product, the estimated energy barrier being unreasonably high. On the other hand, the computed proton affinity of [B2], $232 \mathrm{kcal} \mathrm{mol}^{-1}$, enforces the hypothesis that the hydrogen atom could migrate by acid-base equilibria with the solvent. ${ }^{12}$ Path 2 requires preliminary tautomerization of vinylidene to $\eta^{2}$-alkyne, but the energy difference between these species is quite low, about $1.5 \mathrm{kcal} \mathrm{mol}^{-1}$ in favor of the vinylidene complex. Equilibrium mixtures containing $\eta^{1}$-vinylidene and $\eta^{2}$-alkyne complexes have previously been reported. ${ }^{13}$ However, the greater stability of vinylidene may partially explain the competitive reaction with alcohols and the formation of the corresponding carbenes as prevailing species.

The reaction path involving [B2] was more deeply investigated from a computational point of view. A coordinate-driving study based on the progressive elongation of the $\mathrm{C}(2)-\mathrm{C}(3)$ bond of [B2] (see Scheme 4 for numbering) allowed us to find a possible transition-state geometry, which was then fully optimized and characterized by IR simulations (see the ESI $\uparrow x y z$ file for details of the atomic coordinates). The activation Gibbs free energy (referred to $[\mathrm{Ru}]-\eta^{2}-\mathrm{HC} \equiv \mathrm{CH}+$ methylpropiolate) was $32.7 \mathrm{kcal} \mathrm{mol}^{-1}$, as depicted in Scheme 5. Quite interestingly, the only imaginary frequency $\left(\mathrm{i} 340 \mathrm{~cm}^{-1}\right)$ of the transition state mainly concerns the formation of the $C(2)-C(3)$ bond from $[\mathrm{Ru}]-\eta^{2}-\mathrm{HC} \equiv \mathrm{CH}$ and methylpropiolate. The carbon-oxygen bond of the six-membered heterocycle is instead not yet present in the transition state, the $\mathrm{O}(3) \cdots \mathrm{C}(1)$ distance being about $2.5 \AA$. This result suggests that the 
carbon-oxygen interaction occurs after the $\mathrm{C}(2)-\mathrm{C}(3)$ bond formation, in a secondary step having low activation energy. This idea was supported by a further coordinate-driving simulation based on the progressive elongation of the $\mathrm{O}(3)-\mathrm{C}(1)$ bond of [B2], which did not lead to any $\mathrm{C}-\mathrm{C}$ bond break.

It should be noted that, for the previously reported multicomponent syntheses of $\operatorname{Cr}(0)$ and $\mathrm{W}(0)$ pyranylidene derivatives $^{9}$ from the reaction of carbene complexes with alkylpropiolate in the presence of NMO ( $N$-methylmorpholine$\mathrm{N}$-oxide), the proposed mechanism involved the formation of a propadienylidene intermediate of the type $[\mathrm{M}]=\mathrm{C}=\mathrm{C}=\mathrm{C}\left(\mathrm{O}^{-}\right)$ (OR1), the reaction of which with alkylpropiolate yielded the final pyranylidene complexes. In our case, transformation of vinylidene intermediate $[\mathbf{A}]$ in a propadienylidene species, like that proposed for $\operatorname{Cr}(0)$ and $\mathrm{W}(0)$, is improbable owing to the absence of a base.

Nucleophilic attack of alcohol on the $\mathrm{C} \alpha$ carbon of ruthenium vinylidene complexes affording alkoxycarbene derivatives has previously been reported with unsubstituted $[\mathrm{Ru}]=$ $\mathrm{C}=\mathrm{CH}_{2}$ compounds. ${ }^{14}$ The reaction of our mixed-ligand halfsandwich derivatives with alkylpropiolate highlights a new example of the formation of alkoxycarbene species.

Good analytical data were obtained for both pyranylidene 1, 3 and alkoxycarbene 2, 4 derivatives, which were isolated as yellow-orange solids stable in air and in solution of polar organic solvents, where they behave as $1: 1$ electrolytes. $^{15}$ Infrared and NMR data support the proposed formulations, which were further confirmed by X-ray crystal structure determination of $\left[\mathrm{Ru}\left(\eta^{5}-\mathrm{C}_{5} \mathrm{H}_{5}\right)\{=\mathrm{C}(\mathrm{COOMe}) \mathrm{C}(\mathrm{H}) \mathrm{C}(\mathrm{H}) \mathrm{C}(\mathrm{OMe}) \mathrm{O}\}-\right.$ $\left.\left(\mathrm{PPh}_{3}\right)\left\{\mathrm{P}(\mathrm{OMe})_{3}\right\}\right] \mathrm{BPh}_{4}$ (1), the ORTEP of which is shown in Fig. 1.

Compound 1 consists of a $\mathrm{BPh}_{4}{ }^{-}$anion (not shown in the figure) and a ruthenium cation complex. The latter contains a ruthenium atom in a half-sandwich piano-stool structure, coordinated by a $\eta^{5}$-cyclopentadienyl ligand having one pyran-

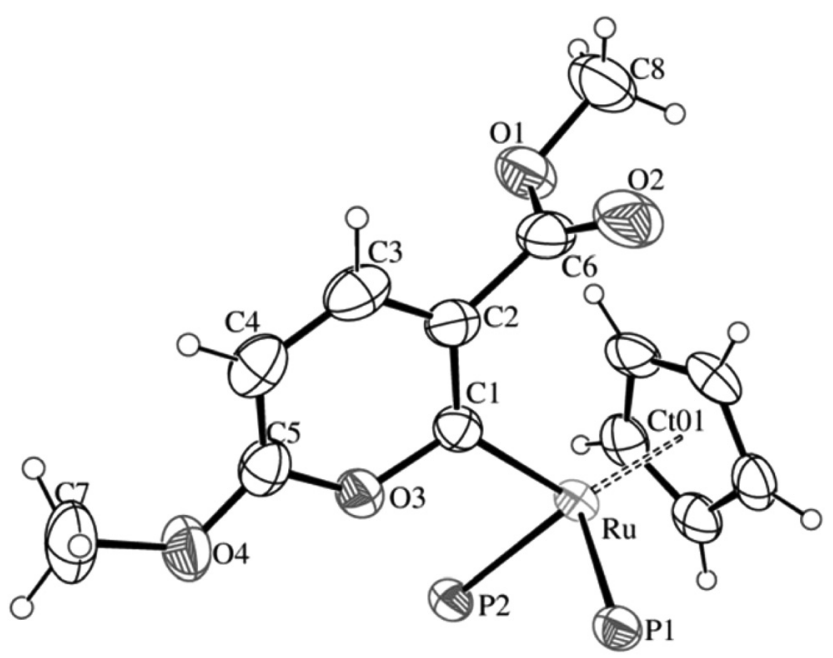

Fig. 1 ORTEP view of the cation of 1 . $\mathrm{P} 1$ represents a $\mathrm{PPh}_{3}$ ligand and $\mathrm{P} 2$ represents a $\mathrm{P}(\mathrm{OMe})_{3}$ ligand.
Table 1 Selected bond lengths $[\AA \AA]$ and angles $\left[^{\circ}\right]$ for 1

\begin{tabular}{llll}
\hline $\mathrm{Ru}-\mathrm{C}(1)$ & $2.018(3)$ & $\mathrm{Ru}-\mathrm{P}(2)$ & $2.2413(8)$ \\
$\mathrm{Ru}-\mathrm{P}(1)$ & $2.3244(8)$ & $\mathrm{Ru}-\mathrm{CT}$ & $1.9136(2)$ \\
$\mathrm{Ru}-\mathrm{C}(11)$ & $2.241(3)$ & $\mathrm{Ru}-\mathrm{C}(12)$ & $2.256(4)$ \\
$\mathrm{Ru}-\mathrm{C}(13)$ & $2.265(4)$ & $\mathrm{Ru}-\mathrm{C}(14)$ & $2.264(3)$ \\
$\mathrm{Ru}-\mathrm{C}(15)$ & $2.257(3)$ & $\mathrm{O}(1)-\mathrm{C}(8)$ & $1.448(6)$ \\
$\mathrm{O}(1)-\mathrm{C}(6)$ & $1.327(5)$ & $\mathrm{O}(3)-\mathrm{C}(5)$ & $1.330(4)$ \\
$\mathrm{O}(2)-\mathrm{C}(6)$ & $1.192(5)$ & $\mathrm{O}(4)-\mathrm{C}(5)$ & $1.307(5)$ \\
$\mathrm{O}(3)-\mathrm{C}(1)$ & $1.392(4)$ & $\mathrm{C}(1)-\mathrm{C}(2)$ & $1.402(5)$ \\
$\mathrm{O}(4)-\mathrm{C}(7)$ & $1.447(5)$ & $\mathrm{C}(2)-\mathrm{C}(6)$ & $1.498(6)$ \\
$\mathrm{C}(2)-\mathrm{C}(3)$ & $1.381(6)$ & $\mathrm{C}(4)-\mathrm{C}(5)$ & $1.350(6)$ \\
$\mathrm{C}(3)-\mathrm{C}(4)$ & $1.384(7)$ & & \\
& & & \\
$\mathrm{C}(1)-\mathrm{Ru}-\mathrm{P}(2)$ & $89.73(10)$ & $\mathrm{C}(1)-\mathrm{Ru}-\mathrm{P}(1)$ & $88.26(9)$ \\
$\mathrm{P}(1)-\mathrm{Ru}-\mathrm{P}(2)$ & $96.56(3)$ & $\mathrm{C}(5)-\mathrm{O}(3)-\mathrm{C}(1)$ & $126.7(3)$ \\
$\mathrm{C}(6)-\mathrm{O}(1)-\mathrm{C}(8)$ & $116.9(4)$ & $\mathrm{O}(3)-\mathrm{C}(1)-\mathrm{C}(2)$ & $112.1(3)$ \\
$\mathrm{C}(5)-\mathrm{O}(4)-\mathrm{C}(7)$ & $118.2(4)$ & $\mathrm{C}(2)-\mathrm{C}(1)-\mathrm{Ru}$ & $132.6(3)$ \\
$\mathrm{O}(3)-\mathrm{C}(1)-\mathrm{Ru}$ & $115.2(2)$ & $\mathrm{C}(3)-\mathrm{C}(2)-\mathrm{C}(6)$ & $116.2(4)$ \\
$\mathrm{C}(3)-\mathrm{C}(2)-\mathrm{C}(1)$ & $121.3(4)$ & $\mathrm{C}(2)-\mathrm{C}(3)-\mathrm{C}(4)$ & $122.6(4)$ \\
$\mathrm{C}(1)-\mathrm{C}(2)-\mathrm{C}(6)$ & $122.5(3)$ & $\mathrm{O}(4)-\mathrm{C}(5)-\mathrm{O}(3)$ & $109.4(3)$ \\
$\mathrm{C}(5)-\mathrm{C}(4)-\mathrm{C}(3)$ & $116.2(4)$ & $\mathrm{O}(3)-\mathrm{C}(5)-\mathrm{C}(4)$ & $120.9(4)$ \\
$\mathrm{O}(4)-\mathrm{C}(5)-\mathrm{C}(4)$ & $129.7(4)$ & $\mathrm{O}(2)-\mathrm{C}(6)-\mathrm{C}(2)$ & $125.8(4)$ \\
$\mathrm{O}(2)-\mathrm{C}(6)-\mathrm{O}(1)$ & $123.6(4)$ & & \\
$\mathrm{O}(1)-\mathrm{C}(6)-\mathrm{C}(2)$ & $110.6(3)$ & & \\
& & &
\end{tabular}

2-ylidene ligand and two phosphines [one $\mathrm{PPh}_{3}$ and one $\mathrm{P}(\mathrm{OMe})_{3}$ ] as legs. Selected bond lengths and angles are shown in Table 1 . The overall geometry of the half-sandwich pianostool complex is octahedral, as demonstrated by near $90^{\circ}$ values for angles $\mathrm{P}-\mathrm{Ru}-\mathrm{P}$ and $\mathrm{P}-\mathrm{Ru}-\mathrm{CO}$, between 88.26(9) and 96.56 $(3)^{\circ}$. The larger angle is that of $\mathrm{P}-\mathrm{Ru}-\mathrm{P}$. The $\eta^{5}$-coordination mode of the $\mathrm{Cp}$ ligand shows $\mathrm{Ru}-\mathrm{C}$ bond distances between 2.241(3) and 2.265(4) $\AA$. The average value for $\mathrm{Ru}-\mathrm{C}$ bond lengths $[2.257(4) \AA]$ is slightly longer than the usual ones for $\mathrm{CpRu}$ moieties, ${ }^{16}$ and the $\mathrm{Ru}-\mathrm{Ct}$ distance [1.9136(2) $\left.\AA\right]$ is also longer than that found, for example, at 1.9056(5) $\AA$ in $\mathrm{Ru}(\mathrm{Cp})\left(\mathrm{GeH}_{3}\right)\left[\mathrm{P}(\mathrm{OMe})_{3}\right]\left(\mathrm{PPh}_{3}\right){ }^{17}$

The $\mathrm{Ru}-\mathrm{P}$ bond distances [2.3244(8) $\AA$ for $\mathrm{Ru}-\mathrm{PPh}_{3}$ and $2.2413(8) \AA$ for $\mathrm{Ru}-\mathrm{P}(\mathrm{OMe})_{3}$ ] are similar to those previously found in other phosphite-phosphine $\mathrm{Ru}(\mathrm{II})$ compounds, e.g., 2.2945(16) and 2.1933(19) ̊̊ in $\mathrm{Ru}(\mathrm{Cp})\left(\mathrm{GeH}_{3}\right)\left[\mathrm{P}(\mathrm{OMe})_{3}\right]\left(\mathrm{PPh}_{3}\right)^{17}$ and 2.3113(4) and 2.2239(5) $\AA$ in $\mathrm{Ru}(\mathrm{Cp}) \mathrm{Cl}\left[\mathrm{P}(\mathrm{OMe})_{3}\right]\left(\mathrm{PPh}_{3}\right){ }^{18}$ Shorter $\mathrm{Ru}-\mathrm{P}$ bonds correspond, as usual, to the phosphite ligand. ${ }^{19}$

The pyran-2-ylidene ligand is bonded to the ruthenium metal with a Ru-C distance of 2.018(3) $\AA$. This is shorter than the usual range for $\mathrm{Ru}-\mathrm{C}\left(\mathrm{sp}^{2}\right)$ single bonds $[2.03-2.11 \AA]^{20,21}$ although slightly longer than that found for other Fischer-type carbene complexes. ${ }^{22}$ The pyran-2-ylidene ring is essentially planar (rms of $0.016 \AA$ ). Distances in the ring (see Table 1) indicate a formal (although short) single bond between $\mathrm{C}(1)$ and $\mathrm{O}(3), 1.392(4) \AA$, and between $\mathrm{C}(1)$ and $\mathrm{C}(2), 1.402(5) \AA$. Electronic delocalization takes place in the rest of the ring, including the $\mathrm{O}(3)-\mathrm{C}(5)$ bond, with values between $1.330(4)$ and 1.384(7) $\AA^{9}{ }^{9}$ The methoxycarbonyl substituent on the pyranylidene ligand is almost perpendicular [dihedral angle between planes of $86.9(2)^{\circ}$ ] to the plane of the rings, proving the single-bond character of the $\mathrm{C}(2)-\mathrm{C}(6)$ bond, with a length of $1.498(6) \AA$. 
The IR spectra of pyranylidene complexes 1, 3 show a medium-intensity band at $1731-1733 \mathrm{~cm}^{-1}$, attributed to the $\nu_{\mathrm{CO}}$ of the ester substituent COOR1. Besides signals of the ancillary ligands and $\mathrm{BPh}_{4}$ anions, the ${ }^{1} \mathrm{H}$ NMR spectra show an $\mathrm{AB}$ quartet at 7.06 and $5.44 \mathrm{ppm}$ for $\mathbf{1}$ and at 7.14 and $5.41 \mathrm{ppm}$ for 3 of the $\mathrm{H} 3$ and $\mathrm{H} 4$ protons of pyranylidene and the signals of methyl or ethyl groups of the COOR1 and OR1 substituents at C2 and C5 atoms, respectively. The methyls of $\mathbf{1}$ appear as singlets at 3.89 and $3.48 \mathrm{ppm}$, and the ethyls of 3 as quartets at 4.42 and 4.17 and triplets at 1.02 and $1.26 \mathrm{ppm}$. However, strong support for the presence of the pyranylidene ligand comes from the ${ }^{13} \mathrm{C}$ NMR spectra, which, at $-30{ }^{\circ} \mathrm{C}$, show the characteristic carbene carbon resonance as a broad multiplet at $332 \mathrm{ppm}$. The spectra show the signals of the $\mathrm{C} 2$, C3, C4 and C5 atoms of the heterocycle ligand between 172 and $94 \mathrm{ppm}$, as well as those of the COOR1 and OR1 substituents, fitting the proposed formulation for pyranylidene complexes.

The NMR proton spectra of alkoxycarbene complexes [Ru$\left.\left(\eta^{5}-\mathrm{C}_{5} \mathrm{H}_{5}\right)\left\{=\mathrm{C}(\mathrm{OR} 2)\left(\mathrm{CH}_{2} \mathrm{COOR} 1\right)\right\}\left(\mathrm{PPh}_{3}\right)\left\{\mathrm{P}(\mathrm{OMe})_{3}\right\}\right] \mathrm{BPh}_{4} \quad(\mathbf{2}, \mathbf{4})$ show an $\mathrm{AB}$ quartet at 4.59-3.89 ppm of the diastereotopic $\mathrm{CH}_{2}$ protons of the $\mathrm{CH}_{2} \mathrm{COOR} 1$ group of carbene and the signals of the substituents R1 and R2, which appear as singlets for methyls and quartets and triplets for ethyls. However, diagnostic of the presence of alkoxycarbene $=\mathrm{C}(\mathrm{OR} 2) \mathrm{CH}_{2} \mathrm{COOR} 1$ are the ${ }^{13} \mathrm{C}$ NMR spectra, which show a doublet of doublets at 297.67-297.21 ppm, attributed to carbene carbon resonance. Singlets at 61.01 for $2 \mathrm{a}, 61.42$ for 2 and $62.85 \mathrm{ppm}$ for $\mathbf{4 a}$ also appear in the spectra which, in an HMQC experiment, were correlated with the $\mathrm{AB}$ quartets at 4.59-3.89 ppm in the proton spectra and were attributed to the methylene carbon resonance of the $\mathrm{CH}_{2} \mathrm{COOR} 1$ group. The signals of the COOR1 and OR2 substituents were also observed, whereas the ${ }^{31} \mathrm{P}$ NMR spectra are $\mathrm{AB}$ quartets, matching the proposed formulation.

\section{Conclusions}

This paper reports the first pyran-2-ylidene carbene complexes of ruthenium prepared through dimerization of alkylpropiolate on a half-sandwich fragment. An alkoxycarbene derivative was also obtained. A reaction path for the formation of the pyranylidene and ethoxycarbene complexes, involving a vinylidene intermediate, is proposed.

\section{Experimental}

\section{Materials and physical measurements}

All synthetic work was carried out under an appropriate atmosphere $\left(\mathrm{Ar}, \mathrm{N}_{2}\right.$ ) by standard Schlenk techniques or in an inert atmosphere dry-box. All solvents were dried over appropriate drying agents, degased on a vacuum line, and distilled in vacuum-tight storage flasks. $\mathrm{RuCl}_{3} \cdot 3 \mathrm{H}_{2} \mathrm{O}$ was a Pressure Chemical Co. (USA) product; other reagents were purchased from commercial sources at the highest available purity and were used as received. Infrared spectra were recorded on a Perkin-Elmer Spectrum-One FT-IR spectrophotometer. NMR spectra $\left({ }^{1} \mathrm{H},{ }^{13} \mathrm{C},{ }^{31} \mathrm{P}\right)$ were obtained on an AVANCE 300 Bruker spectrometer at temperatures between -90 and $+25{ }^{\circ} \mathrm{C}$, unless otherwise noted. ${ }^{1} \mathrm{H}$ and ${ }^{13} \mathrm{C}$ spectra are referred to internal tetramethylsilane. ${ }^{31} \mathrm{P}\left\{{ }^{1} \mathrm{H}\right\}$ chemical shifts are reported with respect to $85 \% \mathrm{H}_{3} \mathrm{PO}_{4}$, with downfield shifts considered positive. COSY, HMQC and HMBC NMR experiments were performed using standard programs. The iNMR software package $^{23}$ was used to treat NMR data. The conductivity of $10^{-3} \mathrm{~mol} \mathrm{dm}^{-3}$ solutions of the complexes in $\mathrm{CH}_{3} \mathrm{NO}_{2}$ at $25^{\circ} \mathrm{C}$ was measured on a radiometer CDM 83. Elemental analyses were performed in the Microanalytical Laboratory of the Dipartimento di Scienze del Farmaco, University of Padova (Italy). Melting points (m.p.) were determined in capillary on Büchi 535 apparatus.

\section{Synthesis of the complexes}

The compound $\operatorname{RuCl}\left(\eta^{5}-\mathrm{C}_{5} \mathrm{H}_{5}\right)\left(\mathrm{PPh}_{3}\right)\left[\mathrm{P}(\mathrm{OMe})_{3}\right]$ was prepared following the method previously reported. ${ }^{24}$

$\left[\mathrm{Ru}\left(\eta^{5}-\mathrm{C}_{5} \mathrm{H}_{5}\right)\{=\overline{\mathrm{C}(\mathrm{COOMe}) \mathrm{C}(\mathrm{H}) \mathrm{C}(\mathrm{H}) \mathrm{C}(\mathrm{OMe}) \mathrm{O}}\}\left(\mathrm{PPh}_{3}\right)\left\{\mathrm{P}(\mathrm{OMe})_{3}\right\}\right]$ $\mathrm{BPh}_{4}$ (1) and $\left[\mathrm{Ru}\left(\eta^{5}-\mathrm{C}_{5} \mathrm{H}_{5}\right)\left\{=\mathbf{C}(\mathrm{OR} 2)\left(\mathrm{CH}_{2} \mathrm{COOMe}\right)\right\}\left(\mathrm{PPh}_{3}\right)\right.$ $\left.\left\{\mathbf{P}(\mathbf{O M e})_{3}\right\}\right] \mathbf{B P h}_{4}(2)[\mathbf{R 2}=\mathbf{M e}(\mathbf{a})$, Et (b)]. In a $25 \mathrm{~mL}$ threenecked round-bottomed flask were placed solid samples of $\operatorname{RuCl}\left(\eta^{5}-\mathrm{C}_{5} \mathrm{H}_{5}\right)\left(\mathrm{PPh}_{3}\right)\left[\mathrm{P}(\mathrm{OMe})_{3}\right](200 \mathrm{mg}, 0.34 \mathrm{mmol})$, an excess of $\mathrm{NaBPh}_{4}(0.68 \mathrm{mmol}, 0.23 \mathrm{~g}), 10 \mathrm{~mL}$ of THF, $2 \mathrm{~mL}$ of the appropriate alcohol $\left(\mathrm{CH}_{3} \mathrm{OH}\right.$ or $\left.\mathrm{C}_{2} \mathrm{H}_{5} \mathrm{OH}\right)$ and an excess of methylpropiolate $(1.6 \mathrm{mmol}, 144 \mu \mathrm{L})$. The reaction mixture was stirred at room temperature for $24 \mathrm{~h}$ and then the solvent was removed by evaporation under reduced pressure. The oil obtained was triturated with alcohol $(3 \mathrm{~mL})$ until a yellow solid separated out, which was filtered and fractionally crystallized by cooling to $-25^{\circ} \mathrm{C}$ the solution of the compound in alcohol and enough $\mathrm{CH}_{2} \mathrm{Cl}_{2}$ to obtain a saturated solution at room temperature. The first separated solid was pyranylidene complex 1 in $22 \%$ average yield (77 mg); ethoxycarbene 2 was the final solid, separated in $62 \%$ yield $(208 \mathrm{mg}$ ) for $2 \mathrm{a}, 63 \%$ (215 mg) for 2b. 1: IR ( $\left.\mathrm{KBr}, \mathrm{cm}^{-1}\right) \nu_{\mathrm{CO}} 1731$ (s); ${ }^{1} \mathrm{H}$ NMR $\left(\mathrm{CD}_{2} \mathrm{Cl}_{2}, 20^{\circ} \mathrm{C}\right) \delta: 7.49-6.87(\mathrm{~m}, 35 \mathrm{H}, \mathrm{Ph}), 4.97\left(\mathrm{~d}, J_{\mathrm{HP}}=0.9 \mathrm{~Hz}\right.$, $5 \mathrm{H}, \mathrm{Cp}), \mathrm{AB}$ spin syst., $\delta_{\mathrm{A}} 7.06, \delta_{\mathrm{B}} 5.44, J_{\mathrm{AB}}=8.7 \mathrm{~Hz}(2 \mathrm{H}, \mathrm{CH})$, 3.89 (s, 3H, $\left.\mathrm{CH}_{3} \mathrm{COOMe}\right), 3.48\left(\mathrm{~s}, 3 \mathrm{H}, \mathrm{CH}_{3} \mathrm{OMe}\right), 3.43$ (d, $J_{\mathrm{HP}}=$ $11.4 \mathrm{~Hz}, 9 \mathrm{H}, \mathrm{CH}_{3}$ phos); ${ }^{31} \mathrm{P}\left\{{ }^{1} \mathrm{H}\right\} \mathrm{NMR}\left(\mathrm{CD}_{2} \mathrm{Cl}_{2}, 20{ }^{\circ} \mathrm{C}\right) \delta: \mathrm{AB}$ spin syst., $\delta_{\mathrm{A}} 148.33, \delta_{\mathrm{B}} 54.31, J_{\mathrm{AB}}=60.27 \mathrm{~Hz} ;{ }^{13} \mathrm{C}\left\{{ }^{1} \mathrm{H}\right\} \mathrm{NMR}$ $\left(\mathrm{CD}_{2} \mathrm{Cl}_{2}, 20{ }^{\circ} \mathrm{C}\right) \delta: 172.77$ (s, C5), 167.93 (s, C6), 165-122 (m, $\mathrm{Ph}$ ), 140.70 (s, C3), 137.08 (s, C2), 94.57 (s br, C4), 89.15 (s, $\mathrm{Cp}), 56.73\left(\mathrm{~s}, \mathrm{OCH}_{3}\right), 53.89$ (d, $J_{\mathrm{CP}}=10.1 \mathrm{~Hz}, \mathrm{CH}_{3}$ phos), 53.03 (s, C8); (at $-30{ }^{\circ} \mathrm{C}$ ) $\delta$ : $332(\mathrm{~m} \mathrm{br}, \mathrm{C} 1)$; Anal. Calcd for $\mathrm{C}_{57} \mathrm{H}_{57} \mathrm{BO}_{7} \mathrm{P}_{2} \mathrm{Ru}$ (1027.89): C, 66.60; H, 5.59; Found: C, 66.38; $\mathrm{H}, 5.71 \% ; \Lambda_{\mathrm{M}}=53.8 \Omega^{-1} \mathrm{~mol}^{-1} \mathrm{~cm}^{2}$; m.p. $155-156^{\circ} \mathrm{C}$ (dec). $2 \mathrm{a}$ : IR $\left(\mathrm{KBr}, \mathrm{cm}^{-1}\right) \nu_{\mathrm{CO}} 1740(\mathrm{~s}) ;{ }^{1} \mathrm{H} \mathrm{NMR}\left(\mathrm{CD}_{2} \mathrm{Cl}_{2}, 20{ }^{\circ} \mathrm{C}\right) \delta$ : 7.50-6.87 (m, 35H, Ph), 5.06 (s, 5H, Cp), AB spin syst., $\delta_{\mathrm{A}} 4.57$, $\delta_{\mathrm{B}} 3.92, J_{\mathrm{AB}}=15.6 \mathrm{~Hz}\left(2 \mathrm{H}, \mathrm{CH}_{2}\right), 3.71\left(\mathrm{~s}, 3 \mathrm{H}, \mathrm{CH}_{3} \mathrm{OMe}\right), 3.60(\mathrm{~s}$, $3 \mathrm{H}, \mathrm{CH}_{3} \mathrm{COOMe}$ ), 3.43 (d, $J_{\mathrm{HP}}=11.4 \mathrm{~Hz}, 9 \mathrm{H}, \mathrm{CH}_{3}$ phos); ${ }^{31} \mathrm{P}$ $\left\{{ }^{1} \mathrm{H}\right\}$ NMR $\left(\mathrm{CD}_{2} \mathrm{Cl}_{2}, 20{ }^{\circ} \mathrm{C}\right) \delta$ : $\mathrm{AB}$ spin syst., $\delta_{\mathrm{A}} 148.83, \delta_{\mathrm{B}} 53.43$, $J_{\mathrm{AB}}=55.65 \mathrm{~Hz} ;{ }^{13} \mathrm{C}\left\{{ }^{1} \mathrm{H}\right\} \mathrm{NMR}\left(\mathrm{CD}_{2} \mathrm{Cl}_{2}, 20{ }^{\circ} \mathrm{C}\right) \delta: 297.39$ (dd, $\left.\mathrm{C}=\mathrm{Ru}, J_{\mathrm{CP}}=12.3, J_{\mathrm{CP}}=17.7 \mathrm{~Hz}\right), 165.05(\mathrm{~s}, \mathrm{C}=\mathrm{O}), 165-122(\mathrm{~m}$, 
$\mathrm{Ph}$ ), 91.30 (d, $\left.J_{\mathrm{CP}}=1.3 \mathrm{~Hz}, \mathrm{Cp}\right), 61.98\left(\mathrm{~s}, \mathrm{CH}_{3} \mathrm{COOMe}\right), 61.01$ (s, $\mathrm{CH}_{2} \mathrm{COO}$ ), 53.67 (d, $J_{\mathrm{CP}}=8.0 \mathrm{~Hz}, \mathrm{CH}_{3}$ phos), 53.36 (s, $\mathrm{OCH}_{3}$ ); Anal. Calcd for $\mathrm{C}_{55} \mathrm{H}_{57} \mathrm{BO}_{6} \mathrm{P}_{2} \mathrm{Ru}$ (987.87): C, 66.87; $\mathrm{H}$, 5.82; Found: C, 66.66; H, 5.70\%; $\Lambda_{\mathrm{M}}=52.5 \Omega^{-1} \mathrm{~mol}^{-1} \mathrm{~cm}^{2} ; \mathrm{m}$. p. $112-113{ }^{\circ} \mathrm{C}$ (dec). 2b: IR ( KBr, cm $\left.{ }^{-1}\right) \nu_{\mathrm{CO}} 1728$ (s); ${ }^{1} \mathrm{H}$ NMR $\left(\mathrm{CD}_{2} \mathrm{Cl}_{2}, 20{ }^{\circ} \mathrm{C}\right) \delta: 7.49-6.87(\mathrm{~m}, 35 \mathrm{H}, \mathrm{Ph}), 5.03\left(\mathrm{~d}, J_{\mathrm{HP}}=1.14\right.$ $\mathrm{Hz}, 5 \mathrm{H}, \mathrm{Cp}), 4.57,3.94$ (d, 2H, $\left.\mathrm{CH}_{2} \mathrm{COO}\right), 4.23,3.55(\mathrm{~m}, 2 \mathrm{H}$, $\mathrm{CH}_{2} \mathrm{OEt}$ ), 3.70 (s, 3H, $\mathrm{CH}_{3} \mathrm{COOMe}$ ), 3.47 (d, $J_{\mathrm{HP}}=11.4 \mathrm{~Hz}, 9 \mathrm{H}$, $\mathrm{CH}_{3}$ phos), 1.12 (t, $\left.J_{\mathrm{HH}}=7.0 \mathrm{~Hz}, 3 \mathrm{H}, \mathrm{CH}_{3} \mathrm{OEt}\right) ;{ }^{31} \mathrm{P}\left\{{ }^{1} \mathrm{H}\right\} \mathrm{NMR}$ $\left(\mathrm{CD}_{2} \mathrm{Cl}_{2}, 20{ }^{\circ} \mathrm{C}\right) \delta$ : $\mathrm{AB}$ spin syst., $\delta_{\mathrm{A}} 148.30, \delta_{\mathrm{B}} 53.05, J_{\mathrm{AB}}=56.30$ $\mathrm{Hz} ;{ }^{13} \mathrm{C}\left\{{ }^{1} \mathrm{H}\right\}$ NMR $\left(\mathrm{CD}_{2} \mathrm{Cl}_{2}, 20{ }^{\circ} \mathrm{C}\right) \delta: 297.21\left(\mathrm{dd}, \mathrm{C}=\mathrm{Ru}, J_{\mathrm{CP}}=\right.$ $\left.12.8, J_{\mathrm{CP}}=18.1 \mathrm{~Hz}\right), 165.10(\mathrm{~s}, \mathrm{C}=\mathrm{O}), 165-122(\mathrm{~m}, \mathrm{Ph}), 91.05$ $\left(\mathrm{dd}, J_{\mathrm{CP}}=2.8 \mathrm{~Hz}, J_{\mathrm{CP}}=1.4 \mathrm{~Hz}, \mathrm{Cp}\right), 72.97$ (d, $J_{\mathrm{CP}}=1.0 \mathrm{~Hz}, \mathrm{CH}_{2}$ OEt), 61.42 (s, $\mathrm{CH}_{2} \mathrm{COO}$ ), 53.70 (d, $J_{\mathrm{CP}}=8.0 \mathrm{~Hz}, \mathrm{CH}_{3}$ phos), 53.36 (s, $\mathrm{CH}_{3} \mathrm{COOMe}$ ), 14.60 (s, $\mathrm{CH}_{3} \mathrm{OEt}$ ); Anal. Calcd for $\mathrm{C}_{56} \mathrm{H}_{59} \mathrm{BO}_{6} \mathrm{P}_{2} \mathrm{Ru}$ (1001.89): C, 67.13; H, 5.94; Found: C, 67.02; $\mathrm{H}, 6.15 \% ; \Lambda_{\mathrm{M}}=53.2 \Omega^{-1} \mathrm{~mol}^{-1} \mathrm{~cm}^{2}$; m.p. $117-118{ }^{\circ} \mathrm{C}$ (dec).

$\left[\mathrm{Ru}\left(\boldsymbol{\eta}^{5}-\mathrm{C}_{5} \mathrm{H}_{5}\right)\{=\overline{\mathrm{C}(\mathrm{COOEt}) \mathrm{C}(\mathrm{H}) \mathrm{C}(\mathrm{H}) \mathrm{C}(\mathrm{OEt}) \mathrm{O}}\}\left(\mathbf{P P h}_{3}\right)\left\{\mathbf{P}(\mathrm{OMe})_{3}\right\}\right]$ $\mathrm{BPh}_{4}$ (3) and $\left[\mathrm{Ru}\left(\boldsymbol{\eta}^{5}-\mathrm{C}_{5} \mathbf{H}_{5}\right)\left\{=\mathrm{C}(\mathrm{OMe})\left(\mathrm{CH}_{2} \mathrm{COOEt}\right)\right\}\left(\mathbf{P P h}_{3}\right)-\right.$ $\left.\left\{\mathbf{P}(\mathbf{O M e})_{3}\right\}\right] \mathbf{B P h}_{\mathbf{4}}$ (4a). These complexes were prepared exactly like the related $\mathbf{1}$ and 2 using ethylpropiolate as a reagent. The two compounds were separated by fractional crystallization by alcohol and $\mathrm{CH}_{2} \mathrm{Cl}_{2}$; yield 14\% (50 mg) for 3, 65\% (221 mg) for 4a. 3: IR ( $\left.\mathrm{KBr}, \mathrm{cm}^{-1}\right) \nu_{\mathrm{CO}} 1733(\mathrm{~s}) ;{ }^{1} \mathrm{H}$ NMR $\left(\mathrm{CD}_{2} \mathrm{Cl}_{2}, 20{ }^{\circ} \mathrm{C}\right)$ $\delta: 7.53-6.87(\mathrm{~m}, 35 \mathrm{H}, \mathrm{Ph}), 7.14,5.41\left(\mathrm{~d}, J_{\mathrm{HH}}=9.0 \mathrm{~Hz}, 2 \mathrm{H}, \mathrm{CH}\right)$, $4.91\left(\mathrm{~d}, J_{\mathrm{HP}}=1.0 \mathrm{~Hz}, 5 \mathrm{H}, \mathrm{Cp}\right), 4.42,4.17\left(\mathrm{q}, J_{\mathrm{HH}}=7.0 \mathrm{~Hz}, 4 \mathrm{H}\right.$, $\mathrm{CH}_{2} \mathrm{OEt}$ ), 3.37 (d, $J_{\mathrm{HP}}=11.5 \mathrm{~Hz}, 9 \mathrm{H}, \mathrm{CH}_{3}$ phos), 1.26, $1.02(\mathrm{t}$, $\left.J_{\mathrm{HH}}=7.0 \mathrm{~Hz}, 6 \mathrm{H}, \mathrm{CH}_{3} \mathrm{OEt}\right) ;{ }^{31} \mathrm{P}\left\{{ }^{1} \mathrm{H}\right\} \mathrm{NMR}\left(\mathrm{CD}_{2} \mathrm{Cl}_{2}, 20{ }^{\circ} \mathrm{C}\right) \delta: \mathrm{AB}$ spin syst., $\delta_{\mathrm{A}} 149.86, \delta_{\mathrm{B}} 55.72, J_{\mathrm{AB}}=57.30 \mathrm{~Hz} ;{ }^{13} \mathrm{C}\left\{{ }^{1} \mathrm{H}\right\}$ NMR $\left(\mathrm{CD}_{2} \mathrm{Cl}_{2},-30{ }^{\circ} \mathrm{C}\right) \delta$ : 355 (br, $\left.\mathrm{C} 1\right)$; Anal. Calcd for $\mathrm{C}_{59} \mathrm{H}_{61} \mathrm{BO}_{7} \mathrm{P}_{2} \mathrm{Ru}$ (1055.94): C, 67.11; H, 5.82; Found: C, 67.23; $\mathrm{H}, 5.74 \% ; \Lambda_{\mathrm{M}}=53.9 \Omega^{-1} \mathrm{~mol}^{-1} \mathrm{~cm}^{2}$; m.p. $73-74{ }^{\circ} \mathrm{C}$ (dec). 4a: IR $\left(\mathrm{KBr}, \mathrm{cm}^{-1}\right) \nu_{\mathrm{CO}} 1731(\mathrm{~s}) ;{ }^{1} \mathrm{H}$ NMR $\left(\mathrm{CD}_{2} \mathrm{Cl}_{2}, 20{ }^{\circ} \mathrm{C}\right) \delta$ : 7.85-6.87 (m, 35H, Ph), 5.06 (d, $\left.J_{\mathrm{HP}}=1.0 \mathrm{~Hz}, 5 \mathrm{H}, \mathrm{Cp}\right), \mathrm{AB}$ spin syst., $\delta_{\mathrm{A}} 4.59, \delta_{\mathrm{B}} 3.89, J_{\mathrm{AB}}=15.6 \mathrm{~Hz}\left(2 \mathrm{H}, \mathrm{CH}_{2} \mathrm{COO}\right), 4.17$ (q, $\left.J_{\mathrm{HH}}=7.0 \mathrm{~Hz}, 2 \mathrm{H}, \mathrm{CH}_{2} \mathrm{OEt}\right), 3.59\left(\mathrm{~s}, 3 \mathrm{H}, \mathrm{CH}_{3} \mathrm{OMe}\right), 3.43$ (d, $J_{\mathrm{HP}}=11.5 \mathrm{~Hz}, 9 \mathrm{H}, \mathrm{CH}_{3}$ phos), $1.28\left(\mathrm{t}, J_{\mathrm{HH}}=7.0 \mathrm{~Hz}, 3 \mathrm{H}, \mathrm{CH}_{3}\right.$ OEt); ${ }^{31} \mathrm{P}\left\{{ }^{1} \mathrm{H}\right\}$ NMR $\left(\mathrm{CD}_{2} \mathrm{Cl}_{2}, 20{ }^{\circ} \mathrm{C}\right) \delta$ : AB spin syst., $\delta_{\mathrm{A}}$ 148.95, $\delta_{\mathrm{B}} 53.42, J_{\mathrm{AB}}=55.41 \mathrm{~Hz} ;{ }^{13} \mathrm{C}\left\{{ }^{1} \mathrm{H}\right\} \mathrm{NMR}\left(\mathrm{CD}_{2} \mathrm{Cl}_{2}, 20{ }^{\circ} \mathrm{C}\right) \delta: 297.67$ $\left(\mathrm{dd}, \mathrm{C}=\mathrm{Ru}, J_{\mathrm{CP}}=12.5, J_{\mathrm{CP}}=17.5\right), 165-122(\mathrm{~m}, \mathrm{Ph}), 164.51(\mathrm{~s}$, COOEt), 91.15 (s, Cp), 62.85 (s, $\mathrm{CH}_{2} \mathrm{COO}$ ), 61.97 (s, $\mathrm{CH}_{2} \mathrm{OEt}$ ), $61.39\left(\mathrm{~s}, \mathrm{OCH}_{3}\right), 53.63\left(\mathrm{~d}, J_{\mathrm{CP}}=8.0 \mathrm{~Hz}, \mathrm{CH}_{3} \mathrm{phos}\right), 14.26(\mathrm{~s}$, $\mathrm{CH}_{3} \mathrm{OEt}$ ); Anal. Calcd for $\mathrm{C}_{56} \mathrm{H}_{59} \mathrm{BO}_{6} \mathrm{P}_{2} \mathrm{Ru}$ (1001.89): C, 67.13; $\mathrm{H}$, 5.94; Found: C, 66.98; $\mathrm{H}, 5.86 \% ; \Lambda_{\mathrm{M}}=51.7 \Omega^{-1} \mathrm{~mol}^{-1} \mathrm{~cm}^{2}$; m.p. $114-115{ }^{\circ} \mathrm{C}$ (dec).

$\left[\mathbf{R u}\left(\boldsymbol{\eta}^{5}-\mathrm{C}_{5} \mathbf{H}_{5}\right)\{=\mathbf{C}=\mathbf{C}(\mathbf{H})(\mathrm{COOMe})\}\left(\mathrm{PPh}_{3}\right)\left\{\mathbf{P}(\mathrm{OMe})_{3}\right\}\right]^{+} \mathbf{O T f}^{-}[\mathrm{A}]$. In a $25 \mathrm{~mL}$ three-necked round-bottomed flask were placed $100 \mathrm{mg}(0.17 \mathrm{mmol})$ of $\mathrm{RuCl}\left(\eta^{5}-\mathrm{C}_{5} \mathrm{H}_{5}\right)\left(\mathrm{PPh}_{3}\right)\left[\mathrm{P}(\mathrm{OMe})_{3}\right], 44 \mathrm{mg}$ $(0.17 \mathrm{mmol})$ of silver triflate, AgOTf, and $7 \mathrm{~mL}$ of dichloromethane. The reaction mixture was stirred for $24 \mathrm{~h}$ in the dark, filtered to remove solid $\mathrm{AgCl}$, and then an excess of methylpropiolate $(0.40 \mathrm{mmol}, 36 \mu \mathrm{L})$ was added. The resulting solution was stirred for $1 \mathrm{~h}$, and then the solvent was removed under reduced pressure to give an oil, which was characterized as such. ${ }^{1} \mathrm{H}$ NMR $\left(\mathrm{CD}_{2} \mathrm{Cl}_{2}, 20{ }^{\circ} \mathrm{C}\right) \delta: 5.27$ (s, 5H, Cp), 5.47 (s br, $1 \mathrm{H},=\mathrm{CH}), 3.89\left(\mathrm{~s}, 3 \mathrm{H}, \mathrm{CH}_{3} \mathrm{COOMe}\right), 3.73\left(\mathrm{~d}, J_{\mathrm{HP}}=11.0 \mathrm{~Hz}\right.$,
9H, $\mathrm{CH}_{3}$ phos $) ;{ }^{31} \mathrm{P}\left\{{ }^{1} \mathrm{H}\right\}$ NMR $\left(\mathrm{CD}_{2} \mathrm{Cl}_{2}, 20{ }^{\circ} \mathrm{C}\right) \delta$ : AB spin syst., $\delta_{\mathrm{A}} 138.86, \delta_{\mathrm{B}} 52.20, J_{\mathrm{AB}}=51.28 \mathrm{~Hz} ;{ }^{13} \mathrm{C}\left\{{ }^{1} \mathrm{H}\right\} \mathrm{NMR}\left(\mathrm{CD}_{2} \mathrm{Cl}_{2}\right.$, $\left.20{ }^{\circ} \mathrm{C}\right) \delta: 199.71(\mathrm{dd}, \mathrm{C} \alpha), 167.82(\mathrm{~s}, \mathrm{CO}), 118.50(\mathrm{~s}, \mathrm{C} \beta), 89.81$ (s, Cp), 54.64 (s, $\mathrm{CH}_{3} \mathrm{COOMe}$ ), 53.11 (d, $\mathrm{CH}_{3}$ phos).

Reaction of $\left[\mathbf{R u}\left(\boldsymbol{\eta}^{5}-\mathbf{C}_{5} \mathbf{H}_{5}\right)\{=\mathbf{C}=\mathbf{C}(\mathbf{H})(\mathbf{C O O M e})\}\left(\mathbf{P P h}_{3}\right)-\right.$ $\left.\left\{\mathbf{P}(\mathrm{OMe})_{3}\right\}\right]^{+}$OTf $^{-}[\mathrm{A}]$ with methylpropiolate. In a $25 \mathrm{~mL}$ threenecked round-bottomed flask containing $0.17 \mathrm{mmol}$ of [A] were added $2 \mathrm{~mL}$ of dichloromethane, an excess of methylpropiolate $(0.40 \mathrm{mmol}, 36 \mu \mathrm{L})$ and $5 \mathrm{~mL}$ of ethanol. The reaction mixture was stirred at room temperature for $24 \mathrm{~h}$ and then the solvent was removed under reduced pressure to give an oil, the ${ }^{1} \mathrm{H}$ and ${ }^{31} \mathrm{P}$ NMR data of which indicated the presence of pyranylidene $\mathbf{1}$ and ethoxycarbene $2 \mathbf{b}$ in about $1: 4$ ratio.

\section{Crystal structure determination}

Crystallographic data for $\mathbf{1}$ were collected at room temperature using a Bruker Smart $6000 \mathrm{CCD}$ detector and $\mathrm{Cu}-\mathrm{K} \alpha$ radiation $(\lambda=1.54178 \AA)$ generated by an Incoatec microfocus source equipped with Incoatec Quazar MX optics. The software APEX2 ${ }^{25}$ was used for collecting frames of data, indexing reflections and the determination of lattice parameters, SAINT $^{25}$ was used for integration of the intensity of reflections, and $\mathrm{SADABS}^{25}$ was used for scaling and empirical absorption correction. The crystallographic treatment was performed with the Oscail program. ${ }^{26}$ The structure was solved by Patterson methods and refined by full-matrix least-squares based on $F^{2}{ }^{27}$ Non-hydrogen atoms were refined with anisotropic displacement parameters. Hydrogen atoms were included in idealized positions and refined with isotropic displacement parameters. Figures were drawn with ORTEP-3 for Windows. ${ }^{28}$ Details of crystal data and structural refinement are given in Table 2. CCDC 1046060 contains the supplementary crystallographic data for this paper.

\section{Computational details}

The computational geometry optimization of the complexes was carried out without symmetry constraints, using the hyper-GGA M06 functional ${ }^{29}$ in combination with a polarized triple- $\zeta$ quality basis set composed of the $6-311 \mathrm{G}(\mathrm{d}, \mathrm{p})$ set on the light atoms and the ECP-based LANL2TZ(f) set on the ruthenium centre. ${ }^{30}$ The "restricted" formalism was applied ${ }^{31}$ and the CPCM implicit solvation model for ethanol was added to all the calculations. ${ }^{32}$ All the stationary points were characterized by IR simulation (harmonic approximation), from which thermodynamic data were computed, considering $T=$ 298.15 K. ${ }^{31}$ The software used was Gaussian $09 .{ }^{33}$ Preliminary geometry optimizations and proton affinity calculations were performed in vacuo with the hybrid DFT functional EDF2 ${ }^{34}$ and the polarized double- $\zeta$ quality basis set LACVP** (LANL2DZ ECP on ruthenium). ${ }^{35}$ The software used for EDF2 calculations was Spartan $08 .{ }^{36}$ All the computational optimizations were performed on an Intel-based x86-64 workstation. 
Table 2 Crystal data and structure refinement for 1

\begin{tabular}{|c|c|}
\hline Empirical formula & $\mathrm{C}_{58} \mathrm{H}_{57} \mathrm{BO}_{7} \mathrm{P}_{2} \mathrm{Ru}$ \\
\hline Moiety formula & $\mathrm{C}_{34} \mathrm{H}_{37} \mathrm{O}_{7} \mathrm{P}_{2} \mathrm{Ru}, \mathrm{C}_{24} \mathrm{H}_{20} \mathrm{~B}$ \\
\hline Formula weight & 1039.86 \\
\hline Temperature & $296(2) \mathrm{K}$ \\
\hline Wavelength & $1.54178 \AA$ \\
\hline Crystal system & Triclinic \\
\hline Space group & $P \overline{1}$ \\
\hline Unit cell dimensions & $\begin{array}{l}a=10.9219(8) \AA \\
b=14.7181(11) \AA \\
c=16.2149(12) \AA \\
\alpha=81.410(4)^{\circ} \\
\beta=87.130(4)^{\circ} \\
\gamma=87.354(3)^{\circ}\end{array}$ \\
\hline Volume & $2572.1(3) \AA^{3}$ \\
\hline$Z$ & 2 \\
\hline Density (calculated) & $1.343 \mathrm{Mg} \mathrm{m}^{-3}$ \\
\hline Absorption coefficient & $3.474 \mathrm{~mm}^{-1}$ \\
\hline$F(000)$ & 1080 \\
\hline Crystal size & $0.140 \times 0.096 \times 0.051 \mathrm{~mm}$ \\
\hline Theta range for data collection & 2.76 to $67.88^{\circ}$ \\
\hline Index ranges & $\begin{array}{l}-12 \leq h \leq 13 \\
-17 \leq k \leq 17 \\
-18 \leq l \leq 19\end{array}$ \\
\hline Reflections collected & 62732 \\
\hline Independent reflections & $9003[R($ int $)=0.0805]$ \\
\hline Reflections observed $(>2 \sigma)$ & 7766 \\
\hline Data completeness & 0.963 \\
\hline Absorption correction & Semi-empirical from equivalents \\
\hline Max. and min. transmission & 0.6970 and 0.5239 \\
\hline Refinement method & Full-matrix least-squares on $F^{2}$ \\
\hline Data/restraints/parameters & $9003 / 0 / 627$ \\
\hline Goodness-of-fit on $F^{2}$ & 1.034 \\
\hline Final $R$ indices $[I>2 \sigma(I)]$ & $\begin{array}{l}R_{1}=0.0497 \\
\mathrm{w} R_{2}=0.1305\end{array}$ \\
\hline$R$ indices (all data) & $\begin{array}{l}R_{1}=0.0577 \\
\mathrm{w} R_{2}=0.1399\end{array}$ \\
\hline Largest diff. peak and hole & 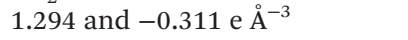 \\
\hline
\end{tabular}

\section{Acknowledgements}

Thanks go to Mrs Daniela Baldan from the Università Ca' Foscari Venezia (Italy) for technical assistance.

\section{References}

1 (a) I. Fernández, F. P. Cossío and M. A. Sierra, Acc. Chem. Res., 2011, 44, 479; (b) J. W. Herndon, Coord. Chem. Rev., 2010, 254, 103; (c) K. H. Dötz and J. Stendel Jr., Chem. Rev., 2009, 109, 3227; (d) M. A. Esteruelas, A. M. López and M. Oliván, Coord. Chem. Rev., 2007, 251, 795; (e) J. Barluenga, J. Santamaría and M. Tomás, Chem. Rev., 2004, 104, 2259; (f) M. A. Esteruelas, A. I. González, A. M. López and E. Oñate, Organometallics, 2003, 22, 414; (g) C.-M. Che and J.-S. Huang, Coord. Chem. Rev., 2002, 231, 151; $(h)$ R. R. Schrock, J. Chem. Soc., Dalton Trans., 2001, 2541; (i) M. A. Sierra, Chem. Rev., 2000, 100, 3591; (j) A. de Meijere, H. Schirmer and M. Duetsch, Angew. Chem., Int. Ed., 2000, 39, 3964; (k) S. F. Vyboishchikov and G. Frenking, Chem. - Eur. J., 1998, 4, 1428; (l) D. G. Musaev, K. Morokuma and N. Koga, J. Chem. Phys.,
1993, 99, 7859; (m) D. S. Marynick and C. M. Kirkpatrick, J. Am. Chem. Soc., 1985, 107, 1993; (n) T. E. Taylor and M. B. Hall, J. Am. Chem. Soc., 1984, 106, 1576.

2 (a) Q.-F. Wang, W. X. Zhang, C. Lin and Z. F. Xi, Chin. Sci. Bull., 2010, 55, 2915; (b) K. N. Juneau, L. S. Hegedus and F. W. Roepke, J. Am. Chem. Soc., 1989, 111, 4762; (c) T. L. Gilchrist, R. Levingston, C. W. Rees, E. von Angerer and R. Robinson, J. Chem. Soc., Perkin Trans. 1, 1973, 2535.

3 (a) N. Szesni, B. Weibert and H. Fischer, Inorg. Chim. Acta, 2006, 359, 617; (b) R. Aumann, A. G. Meyer and R. Fröhlich, J. Am. Chem. Soc., 1996, 118, 10853; (c) R. Aumann, R. A. G. Meyer and R. Fröhlich, Organometallics, 1996, 15, 5018; (d) L. Jordi, F. Camps, S. Ricart, J. M. Viñas, J. M. Moretó, M. Mejias and E. Molins, J. Organomet. Chem., 1995, 494, 53; (e) F. Camps, J. M. Moretó, S. Ricart, J. M. Viñas, E. Molins and C. Miravitlles, J. Chem. Soc., Chem. Commun., 1989, 1560.

4 (a) H. Kusama, T. Sawada, A. Okita, F. Shiozawa and N. Iwasawa, Org. Lett., 2006, 8, 1077; (b) N. Iwasawa, M. Shido, K. Maeyama and H. Kusama, J. Am. Chem. Soc., 2000, 122, 10226; (c) K. Ohe, K. Miki, T. Yokoi, F. Nishino and S. Uemura, Organometallics, 2000, 19, 5525.

5 (a) Q. Wang, L. Lin, C. Lin, H. Sun, W.-X. Zhang and Z. Xi, Dalton Trans., 2009, 10433; (b) Q. Wang, W.-X. Zhang and Z. Xi, Organometallics, 2008, 27, 3627.

6 R. Aumann, K. Roths, B. Jasper and R. Fröhlich, Organometallics, 1996, 15, 1257.

7 (a) H. P. Wu, R. Aumann, R. Fröhlich and B. Wibbeling, Chem. - Eur. J., 2002, 8, 910; (b) S. L. B. Wang and W. D. Wulff, J. Am. Chem. Soc., 1990, 112, 4550.

8 L. Jordi, J. M. Moretó, S. Ricart, J. M. Viñas, E. Molins and C. Miravitlles, J. Organomet. Chem., 1993, 444, C28.

9 B. Baeza, L. Casarrubios, M. Gómez-Gallego, M. A. Sierra and M. Olivan, Organometallics, 2010, 29, 1607.

10 (a) G. Albertin, S. Antoniutti, M. Bortoluzzi, A. Botter and J. Castro, Dalton Trans., 2015, 44, 3439; (b) G. Albertin, S. Antoniutti, A. Botter, J. Castro and M. Giacomello, Organometallics, 2014, 33, 3570; (c) G. Albertin, S. Antoniutti, J. Castro and S. Da Lio, Organometallics, 2013, 32, 3651; (d) G. Albertin, S. Antoniutti, D. Baldan, J. Castro and G. Comparin, Organometallics, 2013, 32, 3157; (e) G. Albertin, S. Antoniutti and J. Castro, Organometallics, 2011, 30, 1914; $(f)$ G. Albertin, S. Antoniutti and J. Castro, Organometallics, 2011, 30, 1558; $(g)$ G. Albertin, S. Antoniutti, F. Callegaro and J. Castro, Organometallics, 2009, 28, 4475; (h) G. Albertin, S. Antoniutti, A. Bacchi, G. Pelizzi and G. Zanardo, Organometallics, 2008, 27, 4407.

11 (a) J. M. Lynam, Chem. - Eur. J., 2010, 10, 8238; (b) M. C. Puerta and P. Valerga, Coord. Chem. Rev., 1999, 193-195, 977; (c) M. I. Bruce, Chem. Rev., 1991, 91, 197.

12 A. Moser, K. Range and D. M. York, J. Phys. Chem. B, 2010, 114, 13911.

13 (a) I. de los Rios, M. Jiménez Tenorio, M. C. Puerta and P. Valerga, J. Am. Chem. Soc., 1997, 119, 6529; (b) V. Cadierno, M. P. Gamasa, J. Gimeno, C. González- 
Bernardo, E. Perez-Carreño and S. Garcia-Granda, Organometallics, 2001, 20, 5177.

14 M. P. Gamasa, J. Gimeno, B. M. Martin-Vaca, J. Borge, S. Garcia-Granda and E. Perez-Carreño, Organometallics, 1994, 13, 4045.

15 W. J. Geary, Coord. Chem. Rev., 1971, 7, 81.

16 A search in the CCDC database CSD version 5.35 (updated in November 2013) gives $1512 \mathrm{CpRu}$ compounds. The mean value for the $\mathrm{Ru}-\mathrm{C}$ bond distance is $2.219 \AA$.

17 G. Albertin, S. Antoniutti, J. Castro and F. Scapinello, J. Organomet. Chem., 2014, 751, 412.

18 F. L. Joslin, J. T. Mague and D. M. Roundhill, Organometallics, 1991, 10, 521.

19 C.-W. Chang, Y.-C. Lin, G.-H. Lee, S.-L. Huang and Y. Wang, Organometallics, 1998, 17, 2534.

20 V. Cadierno, S. Conejero, M. P. Gamasa, J. Gimeno, L. R. Falvello and R. M. Llusar, Organometallics, 2002, 21, 3716.

21 D. J. Armitt, M. I. Bruce, J. C. Morris, B. K. Nicholson, C. R. Parker, B. W. Skelton and N. N. Zaitseva, Organometallics, 2011, 30, 5452.

22 See, for example: (a) Y.-H. Lo, T.-H. Wang, C.-Y. Lee and Y.-H. Feng, Organometallics, 2012, 31, 6887; (b) E. Bustelo, M. Jiménez-Tenorio, M. C. Puerta and P. Valerga, Organometallics, 2007, 26, 4300.

23 G. Balacco, http://www.inmr.net/.

24 G. Albertin, S. Antoniutti, A. Bacchi, G. Pelizzi and G. Zanardo, Organometallics, 2008, 27, 4407.

25 Bruker, APEX2, SMART, SAINT, Bruker AXS Inc., Madison, Wisconsin, USA, 2007.

26 P. McArdle, J. Appl. Crystallogr., 1995, 28, 65.
27 G. M. Sheldrick, Acta Crystallogr., Sect. A: Fundam. Crystallogr., 2008, 64, 112.

28 L. J. Farrugia, J. Appl. Crystallogr., 1997, 30, 565.

29 Y. Zhao and D. G. Truhlar, Theor. Chem. Acc., 2008, 120, 215.

30 (a) A. D. McLean and G. S. Chandler, J. Chem. Phys., 1980, 72, 5639; (b) L. E. Roy, P. J. Hay and R. L. Martin, J. Chem. Theory Comput., 2008, 4, 1029.

31 (a) C. J. Cramer, Essentials of Computational Chemistry, John Wiley and Sons, Chichester, 2nd edn, 2004; (b) F. Jensen, Introduction to Computational Chemistry, John Wiley and Sons, Chichester, 2nd edn, 2007.

32 (a) V. Barone and M. Cossi, J. Phys. Chem. A, 1998, 102, 1995; (b) M. Cossi, N. Rega, G. Scalmani and V. Barone, J. Comput. Chem., 2003, 24, 669.

33 M. J. Frisch, et al., Gaussian 09, Revision C.01, Gaussian, Inc., Wallingford, CT, 2010.

34 C. Y. Lin, M. W. George and P. M. W. Gill, Aust. J. Chem., 2004, 57, 365.

35 (a) W. J. Hehre, R. Ditchfield and J. A. Pople, J. Chem. Phys., 1972, 56, 2257; (b) P. J. Hay and W. R. Wadt, J. Chem. Phys., 1985, 82, 270; (c) M. Dolg, Modern Methods and Algorithms of Quantum Chemistry, ed. J. Grotendorst, John Neumann Institute for Computing, NIC Series, Jülich, 2000, vol. 1, p. 479.

36 Spartan '08, version 1.1.1, Wavefunction, Inc., Irvine, CA, 2009 Except for molecular mechanics and semi-empirical models, the calculation methods used in Spartan have been documented in: Y. Shao, et al., Phys. Chem. Chem. Phys., 2006, 8, 3172. 